\title{
Cancer of the cervix in Ilorin, Nigeria
}

\author{
*M. A. Ijaiya, P. A. Aboyeji and M. O. Buhari*** \\ Departments of Obsterrics and Gynaecology and \\ **Morbid Anatomy and Histopathology \\ University of Ilorin Teaching Hospital, Ilorin, Nigeria.
}

\begin{abstract}
Summary
Objective: The purpose of this study is to review our experience with carcinoma of the cervix in Ilorin, Nigeria.

Method: From 1st January 1990 to 31st December 1999, a total of 169 cases of invasive cervical cancer were seen at the Department of Obstetrics and Gynaecology of the University of Ilorin Teaching Hospital, Ilorin, Nigeria. Results: Carcinoma of the cervix accounted for $63.1 \%$ of histologically confirmed gynaecological cancers. Most of the patients were married $147(98.7 \%)$ and of low socio-economic status $132(88.6 \%)$. One hundred and three $(89.1 \%$ ) patients were in the age bracket $40-69$ years with highest frequency in $40-49$ years age group. The disease is associated with high parity with grandmultiparous patients constituting $119(79.9 \%)$ of the cases. Irregular vaginal bleeding $109(73.2 \%)$, vaginal discharge $58(38.9 \%)$ and postcoital bleeding $\mathbf{3 1}(\mathbf{2 0 . 5 \% )}$ were the common symptoms. Nineteen (12.8\%) patients reported at the hospital within one month of onset of symptoms. A bout three quarter of the patients had advanced disease and stage III disease was the most common stage 75 (50.4\%).

Conclusion: This study has shown a high incidence of carcinoma of cervix at the University of Ilorin Teaching Hospital.
\end{abstract}

Key words: Invasive cervical cancer, Ilorin, Nigeria.

\section{Résumé}

Objectif: Cette étude se propose de revoir notre expérience sur le carcinome cervical à Ilorin, Nigeria.

Méthode: Du 1st janvier 1990 au 31 décembre 1999, 169 cas du cancer cervical invasif sont enregistrés au département de Obsétriques et de la Gynaecologie du Complexe Hospitalier de l'Université d'Ilorin, Nigeria.

Résultat: Le carcinome cervical compte pour $63.1 \%$ du cancer génicologique confirmé histologiquement. La plupart des 147 patients $(98.7 \%)$ sont tous mariés et 132 $(88.6 \%)$ sont d'un statut socio-économique bas. Cent trois patients $(89.1 \%$ ) sont de l'age allant de 40 à 69 ans avec la plus haute fréquence située entre 40 et 49 ans. La maladie est associée a une haute parité avec des patients multipares constituant $119(79.9 \%)$ cas. L'hémorragie vaginale irréguliére avec $109(73.2 \%)$ patients, la décharge vaginale a vec $58(38.9 \%)$ cas et l'hémorragie postcoitale avec $31(20.5 \%)$ cas sont les principaux symptomes.
$19(12.8 \%)$ patients se sont insepits à l'hopit: 1 durant le premier mois de l'apparition des symptomes. J'rés de trois quarts des patients ont une maladie avancée e1 le degré III de la maladie est le niveau le plus connu $75(5), 4 \%)$.

Conclusion: Cette étude montre une haute incience du carcinome cervical au Complexe Hospitalier L'niversitaire d']lorin.

\section{Introduction}

Carcinoma of the cervix, a preventable disease has continued to challenge today's gynaecologist It is a very common gynaecologic malignancy in Nigeria and other parts of Africa ${ }^{1-4}$.

Presently on world-wide basis, cervical c ancer comprises approximately $6 \%$ of all cancer in wome $n^{5}$. An estimated half a million new cases are diagnosed yearly with about 234,000 deaths. About $80 \%$ of the case s are found in developing countries, which have only $5 \%$ of global cancer resources ${ }^{6-8}$

In developed parts of the world, there has been a steady decline in incidence and mortality of the disease as a result of cervical screening programme'. It has been possible to do this because cervical cancer is a slowly evolving disease that begins as a mild dysplsia and progresses over as many as 10 or more years to invasive carcinoma $^{10}$

The aim of this study is to review the experience with carcinoma of the cervix at the Universi y of Ilorin Teaching Hospital, Ilorin, Nigeria.

\section{Materials and methods}

This study was conducted at the Departr ient of $\mathrm{Ob}$ stetrics and Gynaecology of the University of $1 h$ rin Teaching Hospital, Ilorin. All patients with histologica! confirmed cervical carcinoma at the hospital from 1st Jar uary, 1990 to 31 st December 1999 were retrospectively s udied.

There were 236 confirmed gynaecologic al cancers, of which 149 cases were invasive cervical cancer. Information was obtained from patients' case notes and cancer registry record. Data such as age, parity, iducational level, and occupation of patient's husband. clinical symptoms. stage and histological type were ext acted and analysed.

Both patients educational status and thei husbands' occupation were used for social class stratification ${ }^{1+4}$

All gynaecological cancers reviewed were confirmed by 
histological examination or by urinary hCG level as in Chorio-carcinoma.

The following investigations were mandatory: full blood count, electrolytes and urea, liver function tests, intravenous urogram and chest $X$-ray. Endometrial curettage was done when necessary.

Senior Registrars or Consultant gynaecologist performed clinical staging (FIGO staging) of the disease under anaesthesia. Stages $\mathrm{I} / \mathrm{b}$ and above are considered to be advanced disease.

Histological technique-Specimens were fixed in $10 \%$ formalin as soon as obtained. There after Paraffin embed-

\section{Table 1 Age distribution}

\begin{tabular}{lcc}
\hline Age & No. of cases & $\%$ \\
$<20$ & Nil & Nil \\
$20-29$ & 2 & 1.3 \\
$30-39$ & 18 & 12.1 \\
$40-49$ & 41 & 27.5 \\
$50-59$ & 27 & 18.1 \\
$60-69$ & 35 & 23.5 \\
$70-79$ & 17 & 11.4 \\
$\geq 80$ & 9 & 6.0 \\
Total & 149 & 100 \\
\hline
\end{tabular}

Table 2 Parity distribution

\begin{tabular}{lcc}
\hline Age & No. of cases & $\%$ \\
0 & 1 & 0.7 \\
1 & 3 & 2.0 \\
2 & 4 & 2.7 \\
3 & 11 & 7.4 \\
4 & 11 & 7.4 \\
$\square 5$ & 119 & 79.9 \\
Total & 149 & 100 \\
\hline
\end{tabular}

ding and Haemotoxylin and Eosin staining techniques were employed routinely. However, some special stains were sometimes used for better contrast in different components of tissue or in localising the various chemical substances in cells or tissue e.g. Alcian blue, PAS and Masson's trichrome. Senior registrar or Consultant $\mathrm{Pa}$ thologist examined the slides.

\section{Results}

Of the 230 confirmed gyneacological malignancies recorded $149(0.3 .1 \%)$ were invasive cervical cancer. making it the most common gynacological cancer. Two $1.3 \%)$ cases were secondary cervical cancer from endometrial cancer.

One hundred and thity two patients $(88.6 \%)$ were of low socio-economic stalus and $147(98.7 \%)$ were married.
The age range of the patients was $25-85$ years with mean age of 54.7 years. Most of the patients $103(89.1 \%)$ were in the age bracket $40-69$ years. The peak incidence was in $40-49$ years. This is depicted in Table 1.

Table 3 Symptoms

\begin{tabular}{lrr}
\hline & & \\
Variable & No. of cases & $\%$ \\
Irregular vaginal bleeding & 109 & 73.2 \\
Vaginal discharge & 58 & 38.9 \\
Post coital bleeding & 31 & 20.8 \\
Loss of weight & 29 & 19.5 \\
Abdominal pain & 21 & 14.1 \\
Urinary frequency & 17 & 11.4 \\
Passage of urine per vaginam & 8 & 5.4 \\
Backache & 7 & 4.7 \\
Haematochezia & 4 & 2.7 \\
Passage of faeces per vaginam & 2 & 1.3 \\
Many patients had multitude of symptoms & & \\
& & \\
Duration of symptoms (Months) & 19 & 12.8 \\
$<1$ & 45 & 30.2 \\
2 - 3 & 24 & 16.1 \\
$4-5$ & 22 & 14.8 \\
$6-7$ & 39 & 26.2 \\
$\geq 8$ & 149 & 100 \\
Total & & \\
\hline
\end{tabular}

Table 4 Clinical stage

\begin{tabular}{lcc}
\hline Stage & No of cases & $\%$ \\
Ib & 17 & 11.4 \\
$11 \mathrm{a}$ & 20 & 13.4 \\
$1 \mathrm{lb}$ & 18 & 12.1 \\
$1 \mathrm{lla}$ & 19 & 12.8 \\
I I l b & 56 & 37.6 \\
IVa & 16 & 10.7 \\
IVb & 3 & 2.0 \\
Total & 149 & 100 \\
\hline
\end{tabular}

Table 5 Histological pattern

\begin{tabular}{lcc}
\hline Type & No of cases & $\%$ \\
Squamous cell carcinoma & 127 & 85.2 \\
Adenocarcinoma & 8 & 5.4 \\
Adenosquamous earcinoma & 14 & 9.4 \\
Total & 149 & 100 \\
& & \\
Differentiation & & \\
Well differentiated & 53 & 35.6 \\
Moderately diflerentiated & 50 & 33.6 \\
Pootly diliercitiated & 46 & 30.9 \\
Total & 149 & 100 \\
\hline
\end{tabular}

The frequency of the disease rises as parity increases with the highest frequency in grandmultiparous (para 5 
and above) women $119(79.9 \%)$. While patients with low parity (para 2 and below) were few $8(5.4 \%$ ) - Table 2 .

Majority of the patients with cervical cancer had multitude of symptoms. Irregular vaginal bleeding 109 (73.2\%). Vaginal discharge $58(38.9 \%)$ and Postcoital bleeding $31(20.8 \%)$ were the main symptoms experienced. The other symptoms include loss of weight 29 (19.5\%), abdominal pain 21 (14.1\%) and urinary frequency $17(11.4 \%)$. The duration of symptom as at the time of seeking medical attention ranged between 3 days and 10 years. Only $19(12.8 \%)$ reported within one month of onset of symptoms - Table 3 .

One hundred and twelve $(75.2 \%)$ patients presented with advanced stage of the disease while the remaining $37(24.8 \%)$ had early cervical cancer. Stage III was the most common stage 75(50.4\%) This is depicted in Table 4.

Table 5 reveals the histological types of carcinoma of the cervix. Majority of the cases $127(85.2 \%)$ were Squamous cell variety while Adenosquamous carcinoma and Adenocarcinoma accounted for $14(9.4 \%)$ and 8(5.4\%) respectively. Fifty-three (35.6\%) were well differentiated. Closely followed by moderately differentiated 50 (33.6\%) and poorly differentiated cervical cancer $46(30.9 \%)$.

\section{Discussion}

The incidence of $63.1 \%$ of carcinoma of the cervix of all histologically confirmed gynecological malignancies in this study, clearly demonstrates the pre-eminence of cervical cancer in our environment. The finding in this study is similar to the $62.7 \%$ and $72.6 \%$ obtained at Ibadan 5 and Maiduguri ${ }^{16}$ both in Nigeria respectively.

The frequency with which invasive cancer of the cervix occurs is not known exactly but the best incidence data indicate a rate approximately $8-10 / 100,000$ per year ${ }^{\prime \prime}$. Incidence appears to change from one locality to another, however, from various studies ${ }^{1-4}$, there is no doubt that it is the most common gynaecological cancer in many developing countries. Screening procedure is almost nonexisting in many developing countries, a procedure that has led to substantial reduction in incidence, morbidity and mortality of cervical cancer in developed countries.

The age range distribution of our patients is not different from results obtained in other studies ${ }^{15,18,19}$. The peak age of incidence is in the fifth decade which is similar to the findings of Pindiga et $\mathrm{al}^{16}$ and FIGO report of $1986^{\prime \prime}$.

Multiparity has been associated with cervical cancer. It is therefore not surprising that the risk of developing cervical cancer was highest among the grandmultiparous women. This finding is similar to the experience of many workers on the subject ${ }^{12.16 .18 .21}$.

In all probability, the first symptom of early cervical cancer is a thin. watery blood-tinged vaginal discharge that frequently goes unrecognised by the patient ${ }^{1 !}$. In this study, irregular vaginal bleeding was the earliest pre senting symptom. While in Zaria's study. Nigeria '. the earliest presenting symptom was post-coital bleeding. The classical symptom is intermittent painless metrombatal"
Late presentation is a feature of carcirioma of the cervix in developing countries ${ }^{3.6 .12}$ and the lat : symptoms include pain often referred to the flank or $1: \mathrm{g}$, massive haemorrhage and development of uraemia. I I this study, $75 \%$ of the patients had advanced disease due to late presentation. Stage III was the most common presentation, which is similar to the experience from Kumasi, Ghana $^{12}$. In most large series, $85 \%$ to $90 \%$ of c arcinoma of the cervix is squamous cell variety ${ }^{11}$. In this st udy, $85.2 \%$ were squamous cell carcinoma. This is compirable to the $88.0 \%$ and $92 \%$ from $\operatorname{Iran}^{17}$ and Maiduguri $n$ Nigeria ${ }^{16}$ respectively. Adeno-squamous carcinoma ar। aggressive variety constituted $9.4 \%$ in this review. This is higher than the $0-2.1 \%$ of published report ${ }^{16,17,20}$. The rea on for high figure is yet unknown.

Management options available for the teatment of carcinoma of the cervix include surgery, ridiotherapy, chemotherapy and combinations of these mo lalities. For those with cervical cancer stage IIa and less, curative intent with surgery or radiotherapy is usually contemplated. However, with those with advanced disease, radiotherapy is the optimal method of managernent.

In conclusion, this study has shown a high incidence of invasive cervical cancer. This is not differer $t$ from what is obtained in other developing countries. $I 1 /$ the meantime opportunistic screening during antenat: l care, family planning clinic and gynaecological clinic attendance should be introduced.

\section{Acknowledgement}

We wish to acknowledge all the consu tants in the departments of Obstetrics and Gynaecology and Histopathology of the University Teaching Hospitill, Ilorin for allowing us to use their patients' records. 'Ne are also grateful to Mr. John S. Okoji for typing the manuscript.

\section{References}

1. Rafindadi AH, Ifere DI, Shittu SO, Bako $\leadsto, U$, Olasinde TA. A study of some aetiological factors i) 41 cases of cancer of the cervix in Zaria. Nig. Qt. J Hosj'. Med. 1999; 9: $87-89$.

2. Adelusi B. Cancer of the cervix uterine in Ibadan. Nig. Med. J. 1978; 8: $129-132$.

3. Emembolu JO, Ekwempu CC. Carcinoma of the cervix uterine in Zaria: aetiological factors. Int. . Gyn. Obst. 1988: 26: $265-269$.

4. Ojwang SBO, Mati JK. Carcinoma of the cervix in Kenya East. Afr. Med. J. 1978: 55: 194-198.

5. Tewar KS. Disaia PJ. Radiation therapy for g naccological cancer J. Obstet. Gynaced. 2002: 28: 123 - 140.

6. Parkin DM, Pisani P and Ferlay J Estimate of worklwide inciclence ol 25 major cancers in 1990: Int. J Cancer 1999: 80: $827-841$.

Schocll WM. Janicek MF and Mirhashemi fi. Eptdemiol- 
ogy and biology of cervical cancer. Surg. Oncol. 1999: 16 : $203-211$

8. Gharoro EP. Obed HO and Okpere EE. Carcinoma of the cervix: aspects of clinical presentation and management in Benin City. Int. J. Gynaccol. Obstet. 1999; 67: 51 - 53 .

9. Herbst AL. Detection, prevention and treatment of cervical neoplasia: The clinical challenge. Am. J. Obstet Gynaecol. 1996; 175: 1087.

10. Schwarts PE, Hadjimicheal O, Lowel DM, Merino MJ and Janerich D: Rapidly progressive cervical cancer: The Connecticut experience. Am. J. Obstet. Gynaecol 1996; 175: 1105.

11. Dibaia PJ, Creasman WT. Invasive cervical cancer in clinical gynaccology oncology 4th edition. Mosby year book. Boston 1993; 58 - 125.

12. Adadevoh SWK. Clinical presentation of cervical carcinoma in Kumasi, Ghana Int. J. Gynaecol Obstet. 1994; 46: $333-334$

13. Ohacri JU, Campbell OB, Jlesanmi AO and Omigbodun AO. The psychosocial burden of caring for some Nigerian women with breast cancer and cervical cancer. Soc. Sci. Med. 1999; 49: 1541 - 1549 .
14. Olusanya O, Okperc E and Ezimokhai M. The importance of social class in voluntary fertility control in a developing country. West Afr. J. Med. 1985; 4: 205 212 .

15. Babarinsa A, Akang EEU and Adewole IF. Pattern of gynaecological malignancies at the Ibadan Cancer Registry (1976-1995), Nig. Qt. J. Hosp. Med. 1998; 8: 103 106

16. Pindiga UH, EJ-Nafaty AU and Ekanem IA. Female genital malignancies in Maiduguri, Nigeria. A review of 328 cases. Trop. J. Obstet and Gyn. 1999; 16: $52-56$.

17. Haghdel M, Ardakany MS and Zeighami B. Invasive carcinoma of the uterine cervix in Iran. Int. J. Gynaecol. Obstet. 1999; 64: $265-271$.

18. Akinkugbe A. (ed) Premalignant and malignant diseases of the cervix. A textbook of Obstetrics and gynaecology. Evans Brothers Nig. Pub. Ltd. 1996; Pp 393-403.

19. MacSween $R$ and Whaley $\mathrm{K}$ (eds). Malignant tumourrs of the cervix. Muir's Textbook of Pathology. Thirteenth edition. Thompson press. India 1992; pp 1016- 1017.

20. Govan, Hart and Callandar (eds). Carcinoma of the cervix. Gynaecology illustrated. Fourth edition, Churchill Livingstone. Pub. 1993; 216- 224. 